\title{
The Effect of Human Milk on DNA Synthesis of Neonatal Rat Hepatocytes in Primary Culture
}

\author{
YUMI KOHNO, KAZUO SHIRAKI, AND TETSUO MURA \\ Department of Pediatrics [Y.K., K.S.J and Division of Chemistry, Institute of Steroid Research [T.M.], Tottori \\ University School of Medicine, Yonago, Japan
}

\begin{abstract}
We studied the effect of human milk on DNA synthesis of neonatal hepatocytes to elucidate the physiologic role of human milk in growth of the liver. Neonatal hepatocytes were isolated from 5-d-old rats and cultured in serum-free medium. Human milk stimulated DNA synthesis of these hepatocytes in a concentrationdependent manner. The stimulatory activity of $7.5 \%$ ( $\mathrm{rol} /$ vol) human milk plus $0.1 \mu \mathrm{mol} / \mathrm{L}$ insulin was five times that of control and was almost the same as that of $20 \mu \mathrm{g} /$ L human epidermal growth factor (hEGF) plus insulin. The effect of human milk was additive with treatment with hEGF and insulin. The milk associated with prolonged jaundice of infants was significantly more active than the milk that was not associated with jaundice, although the concentration of hEGF was not different between the two types of milk. The mitogenic activity of milk was heatlabile, inactivated by DTT and stable after treatment with trypsin. Three peaks of the activity were detected in milk by gel filtration and the fraction containing proteins of molecular weight between 36000 and 76000 showed the highest activity. Anti-hEGF antibody did not inhibit this activity completely. These results suggested the presence of mitogens other than hEGF or a more active form of hEGF in human milk. The milk associated with breastmilk jaundice exerts a different influence on cell growth and may affect maturation of the liver function related to bilirubin metabolism. The mitogenic activity of milk might be important for growth and development of the liver in infants. (Pediatr Res 29: 251-255, 1991)
\end{abstract}

\section{Abbreviations}

hEGF, human epidermal growth factor mEGF, mouse epidermal growth factor $\mathrm{Mr}$, molecular weight

Human milk is a rich mixture of biologic factors and hEGF is present in a high concentration in milk $(1,2)$. Klagsbrun (3) first reported that human milk contains a mitogenic factor that stimulates DNA synthesis and cell division of fibroblast in vitro. Subsequent studies have shown that this response to human milk can be demonstrated in several types of cells $(1,3-5)$ and hEGF is now known to be one of the major growth factors in milk (5). Parenterally administered mEGF can exert a trophic effect on the liver of adult rats (6). It is also reported that ingested mEGF is absorbed by the intestine and distributed to the liver (7) and

Received May 15, 1990; accepted October 31, 1990.

Correspondence and reprint requests: Yumi Kohno, M.D., Department of Pediatrics. Tottori University School of Medicine, 36-1 Nishi-machi, Yonago 683 Japan.

Supported in part by Grant-in-Aid no. 62570324 from the Ministry of Educaion. Science and Culture of Japan. that orally administered mEGF enhances hepatic incorporation of $\left[{ }^{3} \mathrm{H}\right]$ thymidine into DNA and increases the liver weight of newborn rats $(8,9)$. Therefore, we hypothesized that human milk has the ability to enhance growth in the human neonatal liver and attempted to determine whether this ability is due to the presence of hEGF. We performed our study using neonatal rat hepatocytes in primary culture to isolate the effect of a single factor on DNA synthesis.

It is well known that human milk is associated with prolonged jaundice of breast-fed infants (10). The etiology of the prolonged jaundice is still obscure. Several studies have found that milk has inhibitory effects on uptake, conjugation, and excretion of bilirubin in hepatocytes $(11-13)$. Thus it is thought that some factors in milk might be affecting the immature liver function of bilirubin metabolism. It has also been observed that certain growth factors have an effect on specific liver functions $(9,14-17)$. Orally administered mEGF induces precocious maturation of liver enzymes (9). We therefore examined the second hypothesis, that human milk from mothers whose infants had prolonged jaundice exert a different influence on the growth of the neonatal liver, to elucidate the physiologic role of milk in the immature liver.

\section{MATERIALS AND METHODS}

Human milk samples. Human milk was collected from three groups of mothers at The Tottori University Hospital as shown in Table 1. In two groups, milk was collected at a healthy baby clinic 1 mo after birth (milk-1 and milk-2) and in one group (milk-3) milk was taken from mothers soon after delivery at the bedside to obtain milk at an earlier stage of lactation. All donors had healthy full-term infants on a breast-feeding regimen and had given informed consent to the study. The first group (milk1) was a control group. None of the infants in this group had jaundice and the serum total bilirubin level in all infants was under $103 \mu \mathrm{mol} / \mathrm{L}$. The second group (milk-2) consisted of mothers whose infants had prolonged jaundice. The prolonged jaundice with hyperbilirubinemia (serum total bilirubin $>205$ $\mu \mathrm{mol} / \mathrm{L}$ ) from d 21 to 37 after birth was diagnosed as breastmilk jaundice with no evidence for disease other than breastfeeding. Standard laboratory investigation of prolonged neonatal jaundice $(18)$ was negative. The mean serum indirect-reacting bilirubin level was $239 \mu \mathrm{mol} / \mathrm{L}$ (range 207-267 $\mu \mathrm{mol} / \mathrm{L}$ ). The infants in the third group had no significant jaundice and they required no treatment.

Milk samples were withdrawn manually and $5 \mathrm{~mL}$ midmilk from each mother were obtained for subsequent experiments. All samples from each group were pooled as a large sample and were frozen at $-20^{\circ} \mathrm{C}$ for 1 to 3 mo before analysis. Subsequently, they were thawed and centrifuged at $15000 \times g$ for $60 \mathrm{~min}$ at $4^{\circ} \mathrm{C}$ to remove fat and cellular debris. The supernatant was filtered through a $0.22-\mu \mathrm{m}$ filter (MILLEX-GV, Millipore Co., Bedford, MA) and added to culture in various volumes. The effect of milk on DNA synthesis was tested using milk-1, milk2 , and milk-3. The concentration of total protein in the super- 
natant was measured by the method of Lowry et al. (19) using BSA as a standard and hEGF was quantified by RIA using antihEGF MAb (20).

Treatment of human milk. The supernatant of milk-1 was subjected to the following conditions to characterize the growthpromoting substance in milk. Milk-I was: 1 ) heated at $70^{\circ} \mathrm{C}$ for $20 \mathrm{~min} ; 2$ ) boiled at $90^{\circ} \mathrm{C}$ for $30 \mathrm{~s} ; 3$ ) treated with $1 \mathrm{~mol} / \mathrm{L}$ acetic acid and made up to $\mathrm{pH} 4.5 ; 4)$ treated with $6 \mathrm{~mol} / \mathrm{L} \mathrm{HCl}$ and made up to $\mathrm{pH} 1.3 ; 5$ ) treated with $50 \mathrm{mg} / \mathrm{L}$ trypsin for $2 \mathrm{~h}$ at $37^{\circ} \mathrm{C}$; and 6) treated with DTT for $1 \mathrm{~h}$ at $25^{\circ} \mathrm{C}$.

Gel filtration of milk. A Sephadex G-75 (Pharmacia, Uppsala, Sweden) column $(16 \mathrm{~mm} \times 0.70 \mathrm{~m})$ was equilibrated with distilled water. The column was calibrated by chromatography of proteins of known $\mathrm{Mr}$ and the absorbance was monitored at $280 \mathrm{~nm}$. The supernatant of $10 \mathrm{~mL}$ of milk-1 was applied to the column and eluted at a flow rate of $17.2 \mathrm{~mL} / \mathrm{h}$ to estimate the

Table 1. Characteristics of human milk samples and of suckling infants*

\begin{tabular}{cccccc}
\hline & $\begin{array}{c}\text { Number of } \\
\text { mothers }\end{array}$ & $\begin{array}{c}\text { Days after } \\
\text { delivery }\end{array}$ & $\begin{array}{c}\text { Presence } \\
\text { of } \\
\text { jaundice }\end{array}$ & $\begin{array}{c}\text { Total } \\
\text { protein } \\
(\mathrm{g} / \mathrm{L})\end{array}$ & $\begin{array}{c}\mathrm{hEGF} \\
(\mu \mathrm{g} / \mathrm{L})\end{array}$ \\
\hline Milk-1 & 13 & $21-37$ & $-\dagger$ & 11.8 & 25.2 \\
Milk-2 & 10 & $21-42$ & $+\ddagger$ & 11.5 & 24.7 \\
Milk-3 & 14 & $2-6$ & $-\S$ & 13.5 & 62.3 \\
\hline
\end{tabular}

* Human milk was collected from mothers by manual suction on the days after delivery as indicated, pooled, and frozen at $-20^{\circ} \mathrm{C}$. After centrifugation, the concentrations of total protein (Lowry method) and hEGF (RIA) in the supernatant were measured.

$\dagger$ Without prolonged jaundice (total bilirubin $<103 \mu \mathrm{mol} / \mathrm{L}$ ).

$¥$ Jaundice (total bilirubin $>205 \mu \mathrm{mol} / \mathrm{L}$ ) of infants at 1 mo without any cause other than breast-feeding was diagnosed as the breast-milk jaundice.

$\S$ Without treatment-requiring jaundice.

Table 2. Stimulatory effect of human milk on DNA synthesis of neonatal rat hepatocytes*

\begin{tabular}{lc}
\hline $\begin{array}{c}\text { Additions to primary } \\
\text { culture }\end{array}$ & $\begin{array}{c}\left.{ }^{3} \mathrm{H}\right] \text { thymidine incorporation } \\
\left(\mathrm{dpm} / \mathrm{h} / \mathrm{mg} \text { protein } \times 10^{-4}\right)\end{array}$ \\
\hline None & $1.33 \pm 0.13$ \\
$\mathrm{I}(0.1 \mu \mathrm{mol} / \mathrm{L})$ & $2.11 \pm 0.22$ \\
$\mathrm{I}+\mathrm{hEGF}(20 \mu \mathrm{g} / \mathrm{L})$ & $6.25 \pm 0.37$ \\
Milk-1 $(7.5 \%, \mathrm{vol} / \mathrm{vol})$ & $4.95 \pm 0.24$ \\
Milk-1 $+\mathrm{I}$ & $6.62 \pm 0.60$ \\
Milk- $1+\mathrm{I}+\mathrm{hEGF}$ & $10.21 \pm 0.62 \dagger$ \\
\hline
\end{tabular}

*Values are means \pm SD of six dishes of two separate experiments. I, insulin.

$\dagger p<0.01$ compared with $\mathrm{I}+\mathrm{hEGF}$.
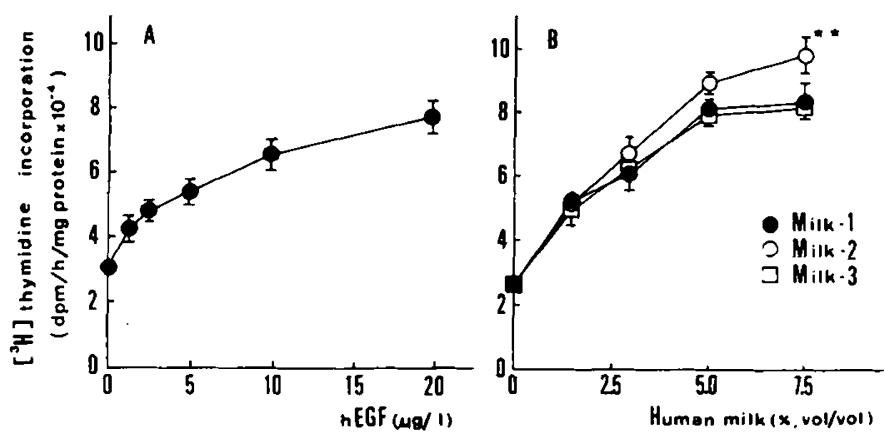

Fig. 1. The stimulatory effect of hEGF $(A)$ and human milk $(B)$ on DNA synthesis of neonatal rat hepatocytes. hEGF and human milk were added to the culture medium with $0.1 \mu \mathrm{mol} / \mathrm{L}$ insulin at various concentrations. DNA synthesis was assayed by measuring incorporation of $\left[{ }^{3} \mathrm{H}\right]$ thymidine in $20 \mathrm{~h} .{ }^{* *}$ Analysis of variance indicated significant differences between milk types $(p<0.01)$ that were concentration dependent.

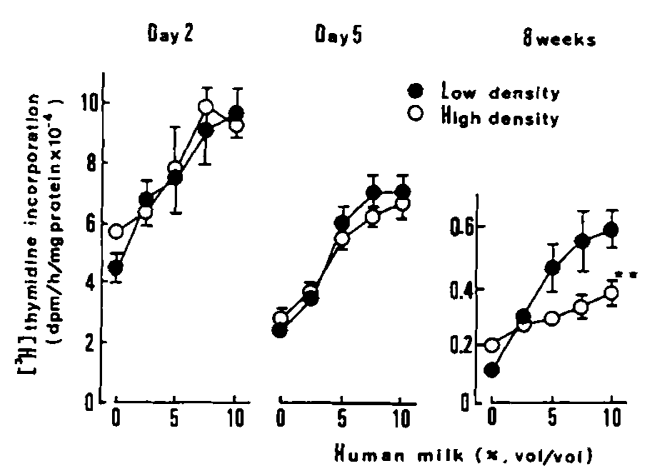

Fig. 2. The stimulatory effect of human milk on DNA synthesis of neonatal (d 2 and 5) and adult ( $8 \mathrm{wk}$, male) rat hepatocytes cultured at low (initial density of $0.65 \times 10^{3}$ cells $\left./ \mathrm{mm}^{2}\right)$ and high $\left(1.3 \times 10^{3}\right.$ cells/ $\mathrm{mm}^{2}$ ) cell densities. Milk- 1 was added with $0.1 \mu \mathrm{mol} / \mathrm{L}$ insulin at various concentrations. ${ }^{* *}$ Analysis of variance indicated significant differences between low and high density only in the adult hepatocytes $(p<0.01)$ that were concentration dependent.

Table 3. Effects of various treatments on DNA synthesisstimulating activity in human milk*

\begin{tabular}{|c|c|c|}
\hline Treatment & $\begin{array}{c}{\left[{ }^{3} \mathrm{H}\right] \text { thymidine }} \\
\text { incorporation } \\
(\mathrm{dpm} / \mathrm{h} / \mathrm{mg} \text { protein } \\
\left.\times 10^{-4}\right)\end{array}$ & $\begin{array}{c}\text { Residual } \\
\text { activity }(\%) \dagger\end{array}$ \\
\hline No addition & $1.35 \pm 0.18$ & \\
\hline $\mathrm{I}(0.1 \mu \mathrm{mol} / \mathrm{L})$ & $1.98 \pm 0.27$ & \\
\hline \multicolumn{3}{|l|}{$\begin{array}{l}\text { Milk-1 }(7.5 \%, \mathrm{vol} / \mathrm{vol})+\mathrm{I}(0.1 \\
\quad \mu \mathrm{mol} / \mathrm{L})\end{array}$} \\
\hline No treatment & $6.50 \pm 0.33$ & 100 \\
\hline $70^{\circ} \mathrm{C}, 20 \mathrm{~min}$ & $1.89 \pm 0.15$ & 0 \\
\hline $90^{\circ} \mathrm{C}, 30 \mathrm{~s}$ & $1.85 \pm 0.39$ & 0 \\
\hline $\mathrm{pH} 4.5$ ( $1 \mathrm{~mol} / \mathrm{L}$ acetic acid $)$ & $6.54 \pm 0.62$ & 100 \\
\hline $\mathrm{pH} 1.3(6 \mathrm{~mol} / \mathrm{L} \mathrm{HCl})$ & $2.60 \pm 0.40$ & 14 \\
\hline $50 \mathrm{mmol} / \mathrm{L} \mathrm{DTT}\left(25^{\circ} \mathrm{C}, 1 \mathrm{~h}\right)$ & $1.77 \pm 0.22$ & 0 \\
\hline $50 \mathrm{mg} / \mathrm{L} \operatorname{tryp} \sin \left(37^{\circ} \mathrm{C}, 2 \mathrm{~h}\right)$ & $5.06 \pm 0.90$ & 68 \\
\hline
\end{tabular}

* Values are means \pm SD of six dishes of two separate experiments. I, insulin.

+ Residual activity is expressed in terms of the activity of milk-1 with no treatment as $100 \%$.

$\mathrm{Mr}$ of the activity in milk-1. Fractions were divided into five groups (F1-F5) and lyophilized. The ability to stimulate DNA synthesis at a dose equivalent to $7.5 \%$ of the original milk was tested in neonatal rat hepatocytes.

Neutralization of milk with anti-hEGF MAb. Human milk and hEGF was treated with anti-hEGF antibody at $37^{\circ} \mathrm{C}$ for $1 \mathrm{~h}$, added to the culture medium at a final concentration of $7.5 \%$ milk and $75 \mathrm{mg} / \mathrm{L}$ anti-hEGF. The stimulation of DNA synthesis by anti-hEGF treated and untreated milk was compared in milk1 and milk-2.

Isolation and primary culture of hepatocytes. Neonatal rats (d 5 , Wistar) were anesthetized with ether and hepatocytes were isolated by the method of Nakamura et al. (21). For digestion of neonatal liver tissue, $0.42 \mathrm{~g} / \mathrm{L}$ collagenase, $0.1 \mathrm{~g} / \mathrm{L}$ trypsin inhibitor, and $5 \mathrm{mmol} / \mathrm{L} \mathrm{CaCl} 2$ in Hanks- $N$-2-hydroxyethylpiperazine- $N^{\prime}$-2-ethanesulfonic acid buffer was used and the liver was perfused with the collagenase solution in situ for $5 \mathrm{~min}$. The cell viability of the final preparation, as determined by the ability to exclude trypan blue, ranged from 93 to $97 \%$. The isolated cells were plated at a density of $0.8 \times 10^{3}$ cells $/ \mathrm{mm}^{2}$ in the wells of plastic dishes (Corning Glass Works, Corning, NY) precoated with highly diluted collagen gel (type I, Nitta Gelatin Co., Yao, Japan). The cells were grown in Williams' $E$ medium with $5 \%$ FCS, $1.0 \mathrm{nmol} / \mathrm{L}$ insulin, and $1.0 \mathrm{nmol} / \mathrm{L}$ dexamethasone and incubated at $37^{\circ} \mathrm{C}$ in an atmosphere of $95 \%$ air and $5 \% \mathrm{CO}_{2}$. 


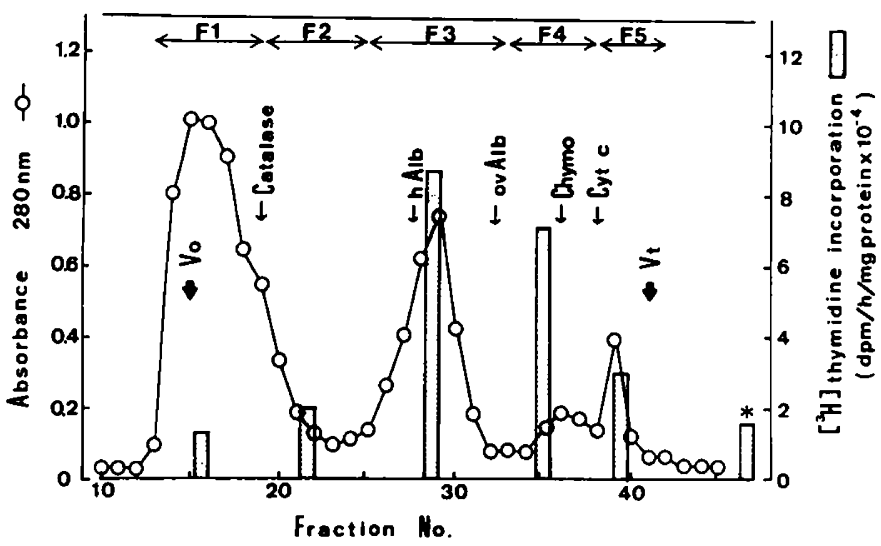

Fig. 3. Gel filtration of human milk. The supernatant $(10 \mathrm{~mL})$ of milk-1 was chromatographed on Sephadex G-75. Fractions $(4.3 \mathrm{~mL} /$ tube) were monitored for absorbance at $280 \mathrm{~nm}$, divided into five groups (Fl-F5), frozen, and lyophylized. They were added to the culture medium with $0.1 \mu \mathrm{mol} / \mathrm{L}$ insulin and the ability to stimulate DNA synthesis was tested in neonatal rat hepatocytes. Values of $\left[{ }^{3} \mathrm{H}\right]$ thymidine incorporation are the means of three dishes. *The incorporation of controls only with $0.1 \mu \mathrm{mol} / \mathrm{L}$ insulin. The following $\mathrm{Mr}$ markers were used: catalase $(250 \mathrm{kD})$, human albumin $(h A l b, 68 \mathrm{kD})$, ovalbumin (ovAlb, 45 $\mathrm{kD}$ ), chymotrypsinogen (Chymo, $25 \mathrm{kD})$, cytochrome c (Cyt c, $12.5 \mathrm{kD})$, blue dextran $(V o)$, and dinitrophenyl-alanine $(V t)$.

Table 4. Effects of hEGF and human milk with or without antihEGF antibody on DNA synthesis of neonatal rat hepatocytes*

\begin{tabular}{lcc}
\hline & \multicolumn{2}{c}{$\begin{array}{c}\left.{ }^{3} \mathrm{H}\right] \text { thymidine incorporation } \\
\left.\text { (dpm/h/mg protein } \times 10^{-4}\right)\end{array}$} \\
\cline { 2 - 3 } \multicolumn{1}{c}{$\begin{array}{c}\text { Additions to } \\
\text { primary culture }\end{array}$} & $\begin{array}{c}\text { Without } \\
\text { anti-hEGF }\end{array}$ & $\begin{array}{c}\text { With anti-hEGF } \\
(75 \mathrm{mg} / \mathrm{L})\end{array}$ \\
\hline None & $1.22 \pm 0.14$ & \\
$\mathrm{I}(0.1 \mu \mathrm{mol} / \mathrm{L})$ & $1.83 \pm 0.26$ & $2.10 \pm 0.21$ \\
hEGF $(5 \mu \mathrm{g} / \mathrm{L})+\mathrm{I}$ & $4.31 \pm 0.35$ & $2.14 \pm 0.44$ \\
hEGF $(20 \mu \mathrm{g} / \mathrm{L})+\mathrm{I}$ & $4.91 \pm 0.48$ & $2.27 \pm 0.60$ \\
Milk-1 $(7.5 \%, \mathrm{vol} / \mathrm{vol})+\mathrm{I}$ & $4.60 \pm 0.49$ & $2.67 \pm 0.39 \dagger$ \\
Milk-2 $(7.5 \%, \mathrm{vol} / \mathrm{vol})+\mathrm{I}$ & $5.17 \pm 0.35 \ddagger$ & $3.16 \pm 0.29 \ddagger \S$ \\
\hline
\end{tabular}

* Values are means \pm SD of six dishes of two separate experiments. I, insulin.

$\dagger p<0.05$ compared with I plus anti-hEGF.

$\ddagger p<0.05$ compared with milk-1 plus I with and without anti-hEGF. $\S p<0.01$ compared with I plus anti-hEGF.

After $3 \mathrm{~h}$, the medium was replaced with serum-and hormone free-medium containing $0.12 \mathrm{mg} / \mathrm{L}$ aprotinin (22).

Assay of DNA synthesis. The medium was replaced again and insulin, hEGF, or human milk were added $24 \mathrm{~h}$ after plating. The cells were then cultured for $36 \mathrm{~h}$ with $\left[{ }^{3} \mathrm{H}\right]$ thymidine present for the last $20 \mathrm{~h}$. Replicative DNA synthesis was assayed by measuring incorporation of $\left[{ }^{3} \mathrm{H}\right]$ thymidine into DNA with or without $10 \mathrm{mg} / \mathrm{L}$ aphidicolin (23). Cellular proteins were measured by the method of Lowry et al. (19).

Materials. The following compounds were purchased from Sigma Chemical Co., St. Louis, MO: insulin, aprotinin, trypsin, trypsin inhibitor, and BSA. FCS was from Flow Laboratories, Rockville, MD and Williams' E medium was from Kyokutou Pharmaceutical Co., Tokyo, Japan. Human EGF and the MAb to hEGF were from Wakunaga Pharmaceutical Co., Hiroshima, Japan. $\left[{ }^{3} \mathrm{H}\right]$ thymidine $(84.8 \mu \mathrm{Ci} / \mathrm{mmol})$ was from DuPont Co., Wilmington, DE. Other chemicals of reagent grade were all from Wako Pure Chemical Industries, Osaka, Japan.

Statistical analysis. All values are reported as means \pm SD. Comparisons of the results were made with unpaired $t$ test and two-way analysis of variance. Differences were considered significant at $p<0.05$.

\section{RESULTS}

Table 1 shows that the concentrations of both total protein and hEGF in milk-1 were the same as those in milk-2. The concentration of hEGF in milk-3, which had been collected at an earlier stage of lactation, was higher than that in milk-1.

Neonatal rat hepatocytes in culture showed the ability to synthesize DNA without the stimulation of any growth factors and that this ability was enhanced by several factors as shown in Table 2. Insulin at a concentration of $0.1 \mu \mathrm{mol} / \mathrm{L}$ stimulated DNA synthesis about 1.5 times the rate of control cells and 20 $\mu \mathrm{g} / \mathrm{L}$ hEGF stimulated DNA synthesis about five times that of controls. Milk-1 at a concentration of $7.5 \%$ (vol/vol) plus 0.1 $\mu \mathrm{mol} / \mathrm{L}$ insulin stimulated DNA synthesis of neonatal hepatocytes as actively as did $20 \mu \mathrm{g} / \mathrm{L}$ hEGF plus insulin. Human milk and hEGF with insulin showed their maximum effects on DNA synthesis at the concentrations of $7.5 \%$ and $20 \mu \mathrm{g} / \mathrm{L}$ respectively, as shown in Figure 1. However, the simultaneous addition of milk-1, insulin, and hEGF markedly stimulated DNA synthesis of neonatal hepatocytes (Table 2). Moreover DNA synthesis was significantly higher than that of insulin plus hEGF $(p<0.01)$. The same results were obtained using milk-2 and milk-3.

Figure $1 A$ shows that hEGF $(0-20 \mu \mathrm{g} / \mathrm{L})$ stimulated DNA synthesis in a concentration-dependent manner. Human milk also stimulated DNA synthesis in a concentration-dependent manner from 0 to $7.5 \%$ as shown in Figure $1 B$. The effect of $10 \%$ milk was the same as that of $7.5 \%$ milk. Although the concentration of hEGF in milk-3 was higher than that in milk1, the DNA synthesis-stimulating activity of milk-3 was the same as that of milk-1. In contrast, the concentration of hEGF was the same in milk-1 and milk-2, yet the stimulating activity of $7.5 \%$ milk-2, which was from mothers of infants with the breastmilk jaundice, was significantly higher than that of milk-1 from mothers of healthy infants $(p<0.01)$.

Furthermore, the effect of human milk on DNA synthesis was compared in younger neonatal rat (d 2) hepatocytes and adult rat $(8 \mathrm{wk}$, male) hepatocytes to determine whether age is a factor in this response to milk. The methods of isolation and culture of the adult rat hepatocytes were the same as those for neonatal hepatocytes, except that a $0.5 \mathrm{~g} / \mathrm{L}$ collagenous solution was used. The stimulation of DNA synthesis by milk-1 was tested in hepatocytes cultured at high (at an initial density of $1.3 \times 10^{3}$ cells $\left./ \mathrm{mm}^{2}\right)$ and low $\left(0.65 \times 10^{3}\right.$ cells $\left./ \mathrm{mm}^{2}\right)$ cell densities. The effect of human milk on DNA synthesis in adult rat hepatocytes was significantly suppressed when hepatocytes had been cultured at a high density as shown in Figure $2(p<0.01)$. At a relatively low density, the effect of $7.5 \%$ milk-1 on DNA synthesis of adult hepatocytes was about four times that of controls, which was similar to the response to $20 \mu \mathrm{g} / \mathrm{L} \mathrm{hEGF}$. The effect on DNA synthesis of neonatal (d 2 and 5) rat hepatocytes was not suppressed even at a high density.

We also tried to characterize the mitogenic substance in milk. Table 3 shows the stability of the activity in milk-1 after various treatments. The effect of milk on DNA synthesis of neonatal hepatocytes decreased markedly after heat treatment and was lost completely after reduction with DTT. The stimulation of DNA synthesis was maintained after treatment with trypsin and with $1 \mathrm{~mol} / \mathrm{L}$ acetic acid ( $\mathrm{pH} 4.5$ ), which precipitated casein in milk. Thus the growth-promoting substance in human milk was heat-labile but acid-stable and resistant to digestion, most likely a protein containing disulfide bridges.

To estimate the $\mathrm{Mr}$ of the growth-promoting factor in human milk, the supernatant of milk-1 was subjected to gel filtration on a Sephadex G-75 column. The ability to stimulate DNA synthesis of five subfractions (Fl-F5) from gel filtration is shown in Figure 3. F3 (Mr 36-76 kD) showed the strongest stimulation of DNA synthesis of neonatal hepatocytes and the activity was five times as high as that of controls. The activity in F4 (12.5-36 kD) was nearly equal to that of F3. We also recognized the activity in F5 (less than $12.5 \mathrm{kD}$ ). We found no ability to stimulate DNA 
synthesis in F1 (more than $250 \mathrm{kD}$ ) and F2 (76-250 kD). In further experiments, the activity was found in three $\mathrm{Mr}$ ranges, which were between human albumin $(68 \mathrm{kD})$ and ovalbumin $(45 \mathrm{kD})$, between chymotrypsinogen $(25 \mathrm{kD})$ and cytochrome $\mathrm{c}$ $(12.5 \mathrm{kD})$, and less than cytochrome $\mathrm{c}$.

Subsequently, we examined immunologically whether the mitogenic factor of human milk for neonatal hepatocytes was hEGF. Table 4 shows the effect on DNA synthesis of milk-1 and milk-2 treated with anti-hEGF MAb. Anti-hEGF antibody at a concentration of $75 \mathrm{mg} / \mathrm{L}$ completely inhibited the activity of 5 $\mu \mathrm{g} / \mathrm{L} \mathrm{hEGF}$. It also inhibited the activity of $20 \mu \mathrm{g} / \mathrm{L} \mathrm{hEGF}$ at the same concentration. In contrast, the addition of $75 \mathrm{mg} / \mathrm{L}$ antihEGF antibody did not completely inhibit the activity of human milk and more than $20 \%$ of original activity remained after treatment with the antibody. The concentration of hEGF in $7.5 \%$ milk was only $1.25 \mu \mathrm{g} / \mathrm{L}$, so $75 \mathrm{mg} / \mathrm{L}$ anti-hEGF represented a large excess of antibody to the hEGF of $7.5 \%$ milk. The effect of human milk treated with anti-hEGF antibody was lower than that of untreated milk. However, the activity of the treated milk was significantly higher than that of the control with insulin and anti-hEGF $(p<0.05, p<0.01)$. Moreover, after the treatment with anti-hEGF, the activity of $7.5 \%$ milk- 2 was higher than that of $7.5 \%$ milk-1 $(p<0.05)$.

\section{DISCUSSION}

We demonstrated that human milk stimulates DNA synthesis of neonatal rat hepatocytes in primary culture. The presence of a growth-promoting activity in human milk has already been demonstrated in several cell lines such as fibroblasts (3), glia (5), and myoblasts (4). Shing et al. (24) purified the growth factor of human milk for cultured fibroblasts and reported that the major growth factor has a $\mathrm{Mr}$ of 6000 and an isoelectric $\mathrm{pH}$ value of 4.5 , and is probably a form of hEGF. In addition, it is known that human milk contains a very high concentration of hEGF $(1,2)$. However, the effect of human milk on neonatal hepatocytes had not yet been studied.

In our study, the differences in DNA synthesis-stimulating activity did not coincide with differences in the concentration of hEGF in milk. The effect of $7.5 \%$ human milk was additive with the maximum effect of insulin plus hEGF. The mitogenic substance of milk has heat-instability characteristics that are different from those of hEGF previously reported (25). Three peaks of the activity were detected in milk by gel filtration and the major peak was not in the fraction of Mr less than 12500 . Carpenter (5) showed that the addition of antibody to hEGF reduces the stimulatory effect of milk by more than $90 \%$ in cultured fibroblasts. In neonatal hepatocytes, more than $20 \%$ of the original activity was residual after the addition of antibody. These results indicate that human milk has growth-promoting activity for neonatal hepatocytes in primary culture and that hEGF could be one of the major factors, but other unknown mitogens are also present in human milk.

The DNA synthesis stimulatory activity of the milk from mothers of infants with breast-milk jaundice was significantly greater than that of the milk from control mothers. The difference in mitogenic ability of two groups was due to the presence of mitogenic factors other than $\mathrm{hEGF}$ because the concentration of hEGF in the two groups was the same. Several growth factors are known to affect the specific functions of liver as well as growth $(9,14-17)$. Orally administered mEGF can induce precocious development of glucokinase (EC 2.7.1.2) activity in the liver and increase bile salt secretion (9). Nakamura et al. (17) have found a reciprocal relation between growth and differentiation of certain enzymatic activities in neonatal hepatocytes in vitro. Thus the growth of neonatal hepatocytes may regulate the expression of specific liver functions. Therefore, we speculated that the unknown growth-promoting substance in milk from mothers of infants with breast-milk jaundice may have inhibitory effects on maturation of liver functions of bilirubin metabolism.
These include the process of uptake, conjugation, and excretion of bilirubin in neonatal hepatocytes. Moreover, a reciprocal relationship between growth and maturation of bilirubin metabolism in liver might be present. A study that reported elevation of serum $\alpha$-fetoprotein in breast-fed infants with jaundice coincides with this speculation (26).

In adult hepatocytes, human milk showed a growth-promoting effect only at a low density as well as in the presence of other growth factors such as insulin, hEGF, and hepatic growth factor $(27,28)$. The hepatocytes cultured at a low density correspond to the liver in regeneration after partial hepatectomy in vivo (28). In contrast, inasmuch as the effect on neonatal hepatocytes was not density-dependent, the trophic effect of milk could be active in normal neonatal liver. The role of growth factors in milk on the growth of the liver might be more important during the neonatal period.

To be active in infants, growth factors in milk would have to survive passage through the stomach, which has a $\mathrm{pH}$ of about 2 to 3 (29) and the gastrointestinal tract, which contains proteolytic enzymes (30). The DNA synthesis stimulating activity contained in milk was stable after treatment with trypsin and with acetic acid (pH 4.5). Britton et al. (31) observed intact survival of hEGF in gastric juice of preterm infants. Orally ingested mEGF absorbed by the intestinal tract can be localized to various somatic organs and it is associated with hepatic and somatic growth in neonatal rats $(7-10,32)$. Therefore, it is possible that the growthpromoting factors in milk that stimulate DNA synthesis of neonatal hepatocytes in vitro could be absorbed in an active form and play a role in the immature liver. In addition, the activity of human milk may be involved in growth and development of the liver in infants.

Acknowledgment. The authors thank Professor Shiro Ikawa for his support and valuable discussion.

\section{REFERENCES}

1. Read LC, Upton FM, Francis GL, Wallace JC, Dahlenberg GW, Ballard FJ 1984 Changes in the growth-promoting activity of human milk during lactation. Pediatr Res 18:133-139

2. Connolly JM, Rose DP 1988 Epidermal growth factor-like proteins in breast fluid and human milk. Life Sci 42:1751-1756

3. Klagsbrun M 1978 Human milk stimulates DNA synthesis and cellular proliferation in cultured fibroblasts. Proc Natl Acad Sci USA 75:5057-5061

4. Sereni A, Baserga R 1981 Routine growth of cell lines in medium supplemented with milk instead of serum. Cell Biol Int Rep 5:339-345

5. Carpenter G 1980 Epidermal growth factor is a major growth-promoting agent in human milk. Science 210:198-199

6. Bucher NL, Patel U, Cohen S 1977 Hormonal factors and liver growth. Adv Enzyme Regul 16:205-213

7. Thornburg W, Matrisian L, Magun B, Koldovsky O 1984 Gastrointestinal absorption of epidermal growth factor in suckling rats. Am J Physiol 246:G80-G85

8. Berseth CL, Go VLW 1988 Enhancement of neonatal somatic and hepatic growth by orally administered epidermal growth factor in rats. J Pediatr Gastroenterol Nutr 7:889-893

9. Opleta K, O'Loughlin EV, Shaffer EA, Hayden J, Hollenberg M, Gall DG 1987 Effect of epidermal growth factor on growth and postnatal development of the rabbit liver. Am J Physiol 253:G622-G626

10. Maiseles MJ, Gifford K 1986 Normal serum bilirubin levels in the newborn and the effect of breast feeding. Pediatrics 78:837-843

11. Cole AP, Hargreaves T 1972 Conjugation inhibitors and early neonatal hyperbilirubinaemia. Arch Dis Child 47:415-418

12. Gourley GR, Arend RA $1986 \beta$-Glucuronidase and hyperbilirubinaemia in breast-fed and formula-fed babies. Lancet 1:644-646

13. Foliot A, Ploussard JP, Housset E, Chiristoforov B 1976 Breast milk jaundice: in vitro inhibition of rat liver bilirubin-uridine diphosphate glucuronyltransferase activity and $\mathrm{Z}$ protein-bromosulfophthalein binding by human breast milk. Pediatr Res 10:594-598

14. Moriarity DM, DiSorbo DM, Litwack G, Savage CR 1981 Epidermal growth factor stimulation of ornithine decarboxylase activity in a human hepatoma cell line. Proc Natl Acad Sci USA 78:2752-2756

15. Kido H, Fukusen N, Katunuma N 1987 Epidermal growth factor as a new regulator of induction of tyrosine aminotransferase and tryptophan oxygenase by glucocorticoids. FEBS Lett 223:223-226

16. Nakamura T, Nagao M, Ichihara A 1987 In vitro induction of neonatal rat hepatocytes by direct contact with adult rat hepatocytes. Exp Cell Res 169:114 
17. Nakamura T, Aoyama K, Ichihara A 1979 Precocious induction of glucokinase in primary cultures of postnatal rat hepatocytes. Biochem Biophys Res Commun 91:515-520

18. Poland RL, Ostrea EM 1986 Neonatal hyperbilirubinamia. In: Klaus $\mathrm{MH}$ Fanaroff (eds) Care of the High-Risk Neonate. Saunders, Philadelphia, pp 239-261

19. Lowry OH, Rosebrough NJ, Farr AL, Randall RJ 1951 Protein measurement with the folin phenol reagent. J Biol Chem 193:265-275

20. Starkey RH, Orth DN 1977 Radioimmunoassay of human epidermal growth factor (Urogastrone). J Clin Endocrinol Metab 45:1144-1153

21. Nakamura T, Fujii T, Ichihara A 1988 Autocrine mechanism of growth of neonatal rat hepatocytes in primary culture. $J$ Biochem 103:700-706

22. Asami O, Nakamura T, Mura T, Ichihara A 1984 Identification of trypsin inhibitor in bovine pituitary extracts as a survival factor for adult rat hepatocytes in primary culture. J Biochem 95:299-309

23. Ikegami S, Taguchi T, Ohashi M, Oguro M, Nagano H, Mano Y 1978 Aphidicolin prevents mitotic cell division by interfering with the activity of DNA polymerase- $\alpha$. Nature 275:458 -460

24. Shing Y, Davidson S, Klagsbrun M 1987 Purification of polypeptide growth factors from milk. Methods Enzymol 146:42-48
25. Cohen S, Carpenter G 1975 Human epidermal growth factor: isolation and chemical and biological properties. Proc Natl Acad Sci USA 72:1317-1321

26. Finni K, Similä S, Koivisto M, Heikura S, Ala-Houhara M 1982 Cholic acid chenodeoxycholic acid, alpha-1-fetoprotein and alpha-1-antitrypsin serum concentrations in breast-fed infants with prolonged jaundice. Eur J Pediatr 138:53-55

27. Richman RA, Claus TH, Pilkis SJ, Friedman DL 1976 Hormonal stimulation of DNA synthesis in primary cultures of adult rat hepatocytes. Proc Natl Acad Sci USA 73:3589-3593

28. Nakamura T, Nawa K, Ichihara A 1984 Partial purification and characterization of hepatocyte growth factor from serum of hepatectomized rats Biochem Biophys Res Commun 122:1450-1459

29. Mason S 1962 Some aspects of gastric function in the newborn. Arch Dis Child 37:387-391

30. Grand RJ, Watkins JB, Torti FM 1976 Development of the human gastrointestinal tract, a review. Gastroenterology 70:790-810

31. Britton JR, Nascimento CG, Udall JN, Koldovsky O 1989 Minimal hydrolysis of epidermal growth factor by gastric fluid of preterm infants. Gut 30:327332

32. Berseth CL 1987 Enhancement of intestinal growth in neonatal rats by epidermal growth factor in milk. Am J Physiol 253:G662-G665 